\title{
Fostering Pre-service STEM Teachers' Technological Pedagogical Content Knowledge: A Lesson Learned from Case-based Learning Approach
}

\author{
Niwat Srisawasdi* \\ Khon Kaen University, Thailand
}

\begin{abstract}
As the recent demand for human resources in science, technology, engineering, and mathematics (STEM), the development of professional STEM teacher is called worldwide. It is becoming a critical need in teacher education in order to educate student teachers, and prepare pre-service and beginning teachers for high quality of teaching competency. To promote the competency for $21^{\text {st }}$ century STEM teachers, the epistemology of technological pedagogical content knowledge (TPACK) is currently considered as the essential qualities of knowledge for highly qualified teachers.

The aim of this study is explore the effect of case-based learning approach on TPACK competency of pre-service STEM teachers. In order to develop the pre-service teachers' competency regarding effective integration of technologies into teaching specific content areas, a series of innovative case study teaching in science and mathematics was presented to 43 participants of pre-service physics, chemistry, biology, mathematics, and computer teachers during a course of information and communication technology (ICT) in Education at Khon Kaen University, Thailand. After finishing a case presentation, the pre-service teachers were encouraged into a forum of critical open discussion by considering the potential impact of the case and the TPACK framework. They were investigated instructional design competency of using ICT tools into student learning process and their personal beliefs about ICT in educational process both before and after. The participant's reactions and learning was evaluated by using a selfreported questionnaire and an implementation log of content-specific learning process design, respectively. Results showed a change of their beliefs and the transformation of their TPACK competency in STEM teaching.

In an effort to better serve the needs of high quality STEM teachers, the results of this study illustrated that the competency of TPACK could be particularly considered as a core attributes for future STEM teachers. By the way, case-based learning approach can play an effective part in preparing and professing the TPACK competency for STEM teachers.
\end{abstract}

Key words: TPACK, ICT, Case-based approach, Pre-service Teacher, STEM

\section{Introduction}

In an alarming trend that can have severe profound and accelerating changes in the $21^{\text {st }}$ century society, educational leaders and policy makers have underscored the importance of STEM-the catchy shorthand for "science, technology, engineering and mathematics"education areas in preparing literate students for more than a decade. Not only all students need a more robust STEM education, but STEM teacher also are need to educate and prepare for gaining high quality of teaching competency. To prepare and create a unique classroom environment for STEM teaching and learning, there is a requirement for comprehensively use of technology in order to develop proficiency in $21^{\text {st }}$ century skills for student, support innovative teaching and learning, and create robust education support system for both students and educators (State Educational Directors Association et al., 2007). Information and communication Technology (ICT) has profound and lasting impacts in school classroom as being a powerful cognitive tool that can transform the way core subject is taught by facilitating both teachers' instructional practices and students' learning processes (Edelson, 2001; Jimoyiannis \&

*Corresponding author: Niwat SRISAWASDI (niwsri@kku.ac.th)

**Received on 31 July 2012, Accepted on 18 October 2012 
Komis, 2007) in order to teach students the knowledge and skills needed for the future knowledge society. STEM leaders and educators value the use of technology to support STEM instruction and they believed that several technologies including probeware, simulation software, and laptop/notebook computers could be used effectively and then impact to student learning in STEM subjects (Interactive Educational Systems Design, 2011).

To meet the challenges in teaching STEM subjects, the rapid growth in use of ICT tools and its features makes it possible to envision dramatic changes in the kinds of instructional environments and then create the unique STEM educational environments in particular support of STEM teaching and learning. For example, new technology and progressive disciplines such as computer modeling and simulation should be incorporated into STEM teaching practices and learning process (Banks \& Sokolowsky, 2010; Huelskamp, 2009). Accordingly, Mayo (2009) reported that video games can yield a 7 to $40 \%$ positive learning increase over a lecture program in STEM disciplines and also suggested that game-based learning approach has the potential to support effective learning in the STEM disciplines. Moreover, Baker (2012) articulated that geographic information system (GIS) technology can engage STEM critical several elements in STEM curriculum and instruction and the GIS is, instructionally, well suited to driving classroom inquiry that is guided by a question, with students collecting data and making analytical conclusions. These articulations provide a suggestion that technology has the potential to disrupt traditional ways of doing things in STEM and engage students in much more authentic, immediate, and interactive STEM learning experience. Therefore, essential knowledge for STEM teachers in this century are called worldwide in order to develop fundamental knowledge of how to use technological tool to pedagogically support student's STEM learning.
To promote the competency for $21^{\text {st }}$ century STEM teachers, the epistemology of technological pedagogical content knowledge (TPACK) is currently considered as the essential qualities of knowledge for highly qualified teachers. Furthermore, viewing of teachers' knowledge as including rich relationships between content, pedagogy, and technology also has significant implications for teacher education and teachers' professional development (Kohler et al., 2007). However, to enhance teacher's performance of integration of technological tool into classroom teaching practices, there also need a transformation of teacher belief about teaching and learning because teachers' knowledge and beliefs about teaching and learning are related to their instructional practices in the classroom (Calderhead, 1996). For the reason, an instructional case-based ICT module has been developed for enhancing STEM teacher's TPACK competency. The goal of this study was to explore an effectiveness of the instructional case-based ICT module in the context of preservice STEM teachers' preparation and development. In order to address the goal, the purpose of this study, therefore, was to investigate the transformation of TPACK in the pre-service STEM teachers and explore their change of personal belief regarding benefits of ICT in education. In addition, the relationships between their TPACK transformation and the change of personal belief toward benefits of ICT in education also were examined. Accordingly, this study, therefore, seeks to first answer the questions that:

1) Does instructional case-based ICT module affect transformations of pre-service STEM teachers' TPACK?

2) Does instructional case-based ICT module affect changes of pre-service STEM teachers' personal belief regarding benefits of ICT in education?

3) What relationship, if any, exists between pre-service STEM teachers' TPACK transformation and their personal belief 
regarding benefits of ICT in education?

\section{Literature Review}

\subsection{Technological Pedagogical Content Knowledge (TPACK)}

The TPACK framework was built upon Shulman's (1986) pedagogical content knowledge (PCK) work, idea of knowledge of pedagogy that is applicable to the teaching of specific content, and it has been embraced as a theoretical basis for structuring ICT curriculum in teacher education programs (Angeli \& Valanides, 2009; Chai et al., 2011; Jimoyiannis, 2010). The TPACK was firstly proposed by Mishra and Koehler (2006) to describe an integrated connection among content knowledge, pedagogical knowledge, and technological knowledge in order to aid the potential integration of ICT tools in classroom setting and school practices, and it is most commonly represented in a drawing of Venn diagram with three overlapping circles of the knowledge. The TPACK diagram includes three core categories of knowledge including the knowledge about the processes and practices or methods of teaching and learning called pedagogical knowledge (PK), the knowledge about the actual subject matter that is to be learned or taught called content knowledge (CK), and the knowledge about standard technologies and the skills required to operate particular technologies called technological knowledge (TK). The Mishra and Koehler (2006)'s framework also proposes that combining these three core types of knowledge results in four additional types of knowledge including the knowledge about particular teaching practice that appropriately fit the nature of specific subject content called pedagogical content knowledge (PCK), the knowledge about the existence, components, and capabilities of standard technologies that could be appropriately used to particularly support in the processes and practices or methods of teaching and learning called technological pedagogical knowledge (TPK), the knowledge about the manner which knowledge of actual subject matter could be manipulated into appropriate representations by the application of standard technologies called technological content knowledge (TCK), and knowledge about the manner which the transactional relationship between knowledge about content $(\mathrm{C})$, pedagogy $(\mathrm{P})$, and technology (T) was dynamic in order to develop appropriate, context-specific, strategies, and representations for better learning of content knowledge called technological pedagogical content knowledge (TPACK). TPACK may provide new directions for teacher educators in solving the problems associated with infusing ICT into classroom teaching practice and learning process (Chai et al., 2011). Researches on teacher education reported that the TPACK model can be used as a potentially fruitful framework to prepare and develop teacher competencies in school teaching (Doering et al., 2009; Lee et al., 2009; Voogt et al., 2009).

\subsection{Case-based Approach}

Cases are a natural and powerful formalism for storing and describing experiential knowledge that is essential to problem solving (Jonassen \& Hernandez-Serrano, 2002), and are authentic situations that are contextually rich and highly memorable for learners (Bonk \& Zhang, 2008). Case-based approach is an inquiry-oriented process that involves either self-directed analysis or collaborative knowledge construction of specific situations based on realworld examples. The method of case-based study was originated from medical and business schools and it was used as active learning pedagogy for exploring particular principles and solving problems (Cranston-Gingrass et al., 1996; Sykes \& Bird, 1992). Case-based approach was determined as a tool for teacher professional preparation and development and it becomes a means for effective method in order to facilitate critical thinking and exploring dilemmas in 
classroom-based teaching (Dori \& Hercovitz, 2005). This approach has been supported within a constructivist learning paradigm in which preservice teachers were provided opportunities to explore various issues within real-life scenarios of student-centered classroom, moving knowledge from theory into practice to become thoughtful practitioner (Lee et al., 2009). In addition, the incorporation of ICT into casebased learning involves understanding the affordances of the technology and the constructivist learning environment.

\section{Method}

\subsection{Study participants}

The participants for this study included 43 pre-service STEM teachers in Graduate Diploma Program in Teaching Profession at Faculty of Education, Khon Kaen University, and they were five physics major, 11 chemistry major, eight biology major, nine mathematics major and 10 computer science major. They were attending a course of information communication technology (ICT) in Education during the $2^{\text {nd }}$ semester of academic year 2010 and they were invited to participate in this research. The participants were aged 21 to 24 years, and about 63\% (27 of 43) were women. All of them did have satisfactory basic ICT skills but they had not any experience with using ICT for teaching before.

\subsection{The Case-based ICT module}

The case-based ICT module consisted of 6 three-hour weekly lecture and the module included six case studies on integrating ICT for STEM education. Table 1 presents the cases and its details of technology, pedagogy, and content used, which used in this study.

After finishing a case presentation, the participants were encouraged into a forum of critical open discussion by considering the potential impact of the case on students' learning and the TPACK framework. The case discussion

\section{Table 1}

Details of the case-based ICT module

\begin{tabular}{|c|c|c|c|c|}
\hline Case & Lesson name & Technology used & Pedagogy used & Content used \\
\hline 1 & $\begin{array}{l}\text { computer-based laboratory } \\
\text { environment for authentic- } \\
\text { inquiry science }\end{array}$ & $\begin{array}{l}\text { Computer-based } \\
\text { laboratory }\end{array}$ & $\begin{array}{l}\text { Inquiry-based } \\
\text { learning }\end{array}$ & $\begin{array}{l}\text { Nanoscience and } \\
\text { technology of smell } \\
\text { (Nanoscience) }\end{array}$ \\
\hline 2 & $\begin{array}{l}\text { Virtual computer-based } \\
\text { laboratory environment for } \\
\text { chemistry learning }\end{array}$ & Computer simulation & $\begin{array}{l}\text { Inquiry-based } \\
\text { learning }\end{array}$ & $\begin{array}{l}\text { Water contact angle } \\
\text { (Chemistry) }\end{array}$ \\
\hline 3 & $\begin{array}{l}\text { Symbolic tool set for integral } \\
\text { problem solving in } \\
\text { mathematics learning }\end{array}$ & Maple software & $\begin{array}{l}\text { Problem-based } \\
\text { learning }\end{array}$ & $\begin{array}{l}\text { Calculus } \\
\text { (Mathematics) }\end{array}$ \\
\hline 4 & $\begin{array}{l}\text { Constructivist web-based } \\
\text { learning environment for } \\
\text { physics learning }\end{array}$ & $\begin{array}{l}\text { Web-based learning } \\
\text { environment }\end{array}$ & $\begin{array}{l}\text { Constructivist } \\
\text { learning }\end{array}$ & $\begin{array}{l}\text { Force and laws of } \\
\text { motion (Physics) }\end{array}$ \\
\hline 5 & $\begin{array}{l}\text { Testing and diagnostic } \\
\text { learning problem : an } \\
\text { educational application from } \\
\text { computer science }\end{array}$ & $\begin{array}{l}\text { Web-based Artificial } \\
\text { intelligence }\end{array}$ & $\begin{array}{l}\text { Web-based } \\
\text { learning }\end{array}$ & $\begin{array}{l}\text { System of linear } \\
\text { equation } \\
\text { (Mathematics) }\end{array}$ \\
\hline 6 & $\begin{array}{l}\text { Geographic information } \\
\text { system tool for teaching } \\
\text { biology }\end{array}$ & $\begin{array}{l}\text { Geographic } \\
\text { information system } \\
\text { (GIS) }\end{array}$ & $\begin{array}{l}\text { Inquiry-based } \\
\text { learning }\end{array}$ & $\begin{array}{l}\text { Mollusk diversity } \\
\text { and distribution } \\
\text { (Biology) }\end{array}$ \\
\hline
\end{tabular}


is aligned to the criteria for ICT-TPACK (Angeli \& Valanides, 2009) comprising: (a) identification of suitable topic to be taught with technology; (b) identification of appropriate representations to transform content; (c) identification of teaching strategies difficult to be implemented by traditional mean; (d) selection of appropriate tools and appropriate pedagogical uses of their affordances; and (e) identification of appropriate integration strategies.

\subsection{Data collection}

An assessment method of teacher's performance on different design tasks over a period of time was used to evaluate the participants' TPACK competency in this study. For investigating the TPACK transformation of the participants, the two design tasks of using ICT tools into their teaching practice and student learning process constituted the unit of analysis. On each design task, they were asked to design technology-enhanced teaching practices and learning activities for a topic of their choice. The first design task was assigned to the participants in the first week of the case-based ICT module, before the presentation of the first case study. At the end of the module, the participants were given a second design task and were asked to complete it in the last week. Also, all the participants were asked to respond to a 17-item survey instrument, which obtained from Jimoyiannis \& Komis (2007), for exploring their belief about ICT in education both before and after attending the case-based ICT module. The instrument was a Likert-type scale containing items that present statement of belief about ICT as a teaching and learning tools (6 items), belief about ICT integration in education (6 items), and belief about ICT in the educational process ( 5 items). Each item rated the participants' belief using a five-point-scale ranging from "strongly disagree" (1 point) to "strongly agree" (5 points).

\subsection{Data analysis}

For the analysis of the transformation of
TPACK competency for the participants, the content analysis was primarily used for the analysis of their design tasks. Content analysis can involve both numeric (quantitative) and interpretive data analyses (qualitative), or combinations of both (Koehler et al., 2007). A coding system of protocols consistent with the TPACK framework was developed, as presents in Table 2, and then the design tasks were coded based on the seven categories defined by the TPACK framework, including Content Knowledge (CK), Pedagogical Knowledge (PK), Technological Knowledge (TK), Pedagogical Content Knowledge (PCK), Technological Content Knowledge (TCK), Technological Pedagogical Knowledge (TPK), and Technological Pedagogical and Content Knowledge (TPACK). To determine their TPACK based on this framework, the design tasks responses are scored on two scales (score 0: no answer/ incomplete answer, score 1: complete answer) on each category of knowledge as having.

To analyze the pre-service STEM belief about ICT in education, descriptive statistics was used to process the students' responses from the questionnaire.

\section{Results and Discussion}

\subsection{Results for teachers' TPACK competency}

From the content analysis, the pre-service STEM teachers' response on the design tasks were coded inductively and then identified their TAPCK throughout the design process. Table 2 shows example results of the pre-service STEM teachers' TPACK for each of the categories used to code their response on the design tasks.

In Table 3 that follows, it presents the percentage of coded segments over the first and second design tasks for each of seven categories, as abovementioned. The statistical analyses of the data suggest that there are some differences between the first and the second design tasks that the percentage of CK, TK, PCK, TCK, TPK, and TPACK for the first design task is greater 


\section{Table 2}

Percentage of each coding category for both design tasks

\begin{tabular}{|c|c|c|c|}
\hline Code & Category & Scoring description & Example \\
\hline CK & $\begin{array}{l}\text { Content } \\
\text { Knowledge }\end{array}$ & $\begin{array}{l}\text { Identification of conceptual } \\
\text { knowledge in science, or } \\
\text { difficulty of scientific } \\
\text { knowledge representation }\end{array}$ & $\begin{array}{l}\text { (On the first design task) Std_01: She described } \\
\text { a conceptual domain of her teaching design } \\
\text { task that teaching property of sound need to } \\
\text { cover reflection, refraction, interference, and } \\
\text { diffraction properties of sound wave. }\end{array}$ \\
\hline
\end{tabular}

\begin{tabular}{lll}
\hline PK & $\begin{array}{l}\text { Pedagogical } \\
\text { Knowledge }\end{array}$ & $\begin{array}{l}\text { Identification of teaching } \\
\text { methods, classroom } \\
\text { management, instructional } \\
\text { practices }\end{array}$ \\
\hline TK & $\begin{array}{l}\text { Technological } \\
\text { Knowledge }\end{array}$ & $\begin{array}{l}\text { Identification of technology } \\
\text { used for scientific concept } \\
\text { teaching and learning }\end{array}$
\end{tabular}

(On the first design task) Std_01: She suggested using hands-on experiment for teaching practice of sound wave property.

(On the first design task) Std_01: She mentioned that Excel spreadsheet software can be used in collecting experimental data and also graphing the data visually.

\begin{tabular}{ll}
\hline PCK & Pedagogical \\
& Content \\
Knowledge
\end{tabular}

Explanation of pedagogies, teaching practices, or planning processes related to specific conceptual knowledge or representations in science

(On the second design task) Std_03: He explained that teacher can use digital picture of parabolic motion of projectile on objects for presenting and discussing about characteristics of a projectile trajectory.

\begin{tabular}{ll}
\hline TCK & Technological \\
& Content \\
& Knowledge
\end{tabular}

Explanation of technologies which could be used to create or transform specific conceptual knowledge or representations in science
(On the second design task) Std_02: She suggested using microcomputer-based laboratory (MBL) in teaching practice of conservation law of energy topic and explained that the MBL provide the possibility of displaying graphs of potential and kinetic energy in a real -time.

(On the second design task) Std_02: She described that using hands-on MBL activity could provide additional engagement of learning to student. Also, student are provided opportunity into active science learning instead of passive learning of science by lecturingctivity could provide additional engagement of learning to student.

(On the second design task) Std_01: She designed teaching practice by integrating MBL with computer simulation into inquiry-based learning activity and explained that the MBL could be used in student' s group exploration and the simulation could be used for discussion and elaboration of the property of sound wave concepts because of its observable phenomenon

\begin{tabular}{llll}
\hline TPACK & $\begin{array}{l}\text { Technological } \\
\text { Pedagogical }\end{array}$ & $\begin{array}{l}\text { Explanation of integrating } \\
\text { technologies into teaching }\end{array}$ & $\begin{array}{l}\text { (On the second design task) Std_01: She } \\
\text { designed teaching practice by integrating MBL }\end{array}$ \\
Knowledge & $\begin{array}{l}\text { practice or learning } \\
\text { process in order to } \\
\text { enhance understanding of } \\
\text { specific conceptual } \\
\text { knowledge or } \\
\text { representations in science }\end{array}$ & $\begin{array}{l}\text { learning activity and explained that the MBL } \\
\text { could be used in student's group exploration } \\
\text { and the simulation could be used for discussion } \\
\text { and elaboration of the property of sound wave } \\
\text { concepts because of its observable phenomenon }\end{array}$ \\
&
\end{tabular}

than the second design task, except for the percentage of $\mathrm{P}$.

A graphical representation of the Table 2 is provided in Fig. 1, which allows us to see some interesting transformation of TPACK competency for the pre-service STEM teachers.

In a summary, the results provided evidence that the pre-service STEM teachers' TPACK 
Table 3

Percentage of each coding category for both design tasks

\begin{tabular}{cccccccc}
\hline \hline \multirow{2}{*}{$\begin{array}{c}\text { Design } \\
\text { task }\end{array}$} & CK & PK & TK & PCK & TCK & TPK & TPACK \\
\cline { 2 - 7 } & 30.23 & 100.00 & 97.67 & 16.27 & 27.90 & 90.67 & 13.95 \\
\hline $\begin{array}{c}\text { First } \\
(\mathrm{N}=43)\end{array}$ & 70.00 & 100.00 & 100.00 & 70.00 & 67.50 & 97.50 & 65.00 \\
\hline $\begin{array}{c}\text { Second } \\
(\mathrm{N}=40)\end{array}$ & & & & &
\end{tabular}

competency has been transformed through the case-based ICT module. The results also reflect that the pre-service STEM teacher can present their knowledge of content (CK), pedagogical content (PCK), technological content (TCK), and technological pedagogical content (TPACK) more fully after attending the module. The result is consistent with research findings that casebased teaching for teacher professional development induced a significant change in their abilities high-quality learning activities (Dori \& Hercovitz, 2005). Moreover, Chai et al. (2011) reported the use of the core ICT module to model pre-service teachers' TPACK that the pre-service teachers' perceived relations between content knowledge and TPACK changes form insignificant to significant. An implication of this is the possibility that case-based learning approach can be a potential method for the development of pre-service teacher's TPACK competency in order to facilitate the application of the knowledge learnt from the cases into their own classroom situations and insight into alternative solutions for their teaching practice.

\subsection{Results for teachers' belief regarding benefits of ICT in education}

Table 4 shows the mean and standard deviation of pre-test and post-test on the belief about ICT as a teaching and learning tool (ICTTool), belief about ICT integration in education (ICT-Integration), and belief about ICT in the educational process (ICT-Process) for pre-test and post-test. The statistical analyses of the data suggest that there are some differences between the pre-test and post-test scores for teachers' belief about ICT in education that the mean of ICT-Tool and ICT-Process for the post-
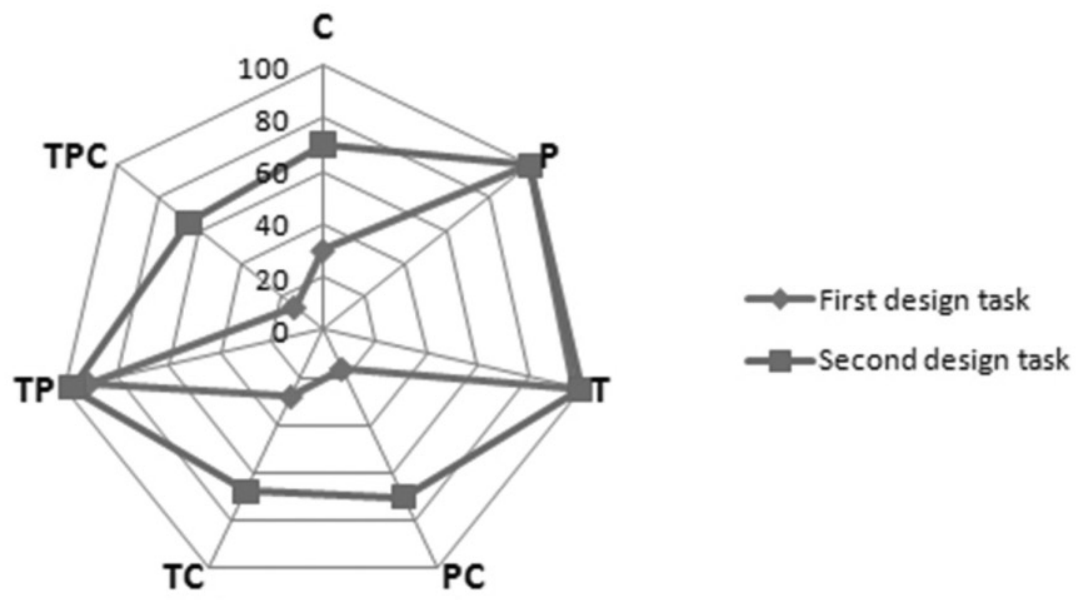

Fig. 1 Graphical representation of overall TPACK transformation of pre-service STEM teachers 


\section{Table 4}

Mean and standard deviation of each dimension for pre-service teachers' belief about ICT in education

\begin{tabular}{cccc}
\hline \hline \multirow{2}{*}{ Testing } & \multicolumn{3}{c}{ Dimension of belief about ICT in education } \\
\cline { 2 - 4 } & ICT-Tool & ICT-Integration & ICT-Process \\
\hline $\begin{array}{c}\text { Pre-test } \\
(\mathrm{N}=43)\end{array}$ & $3.80(0.81)$ & $3.76(0.68)$ & $3.37(0.45)$ \\
\hline $\begin{array}{c}\text { Post-test } \\
(\mathrm{N}=40)\end{array}$ & $3.96(0.59)$ & $3.81(0.90)$ & $3.50(0.44)$ \\
\hline
\end{tabular}

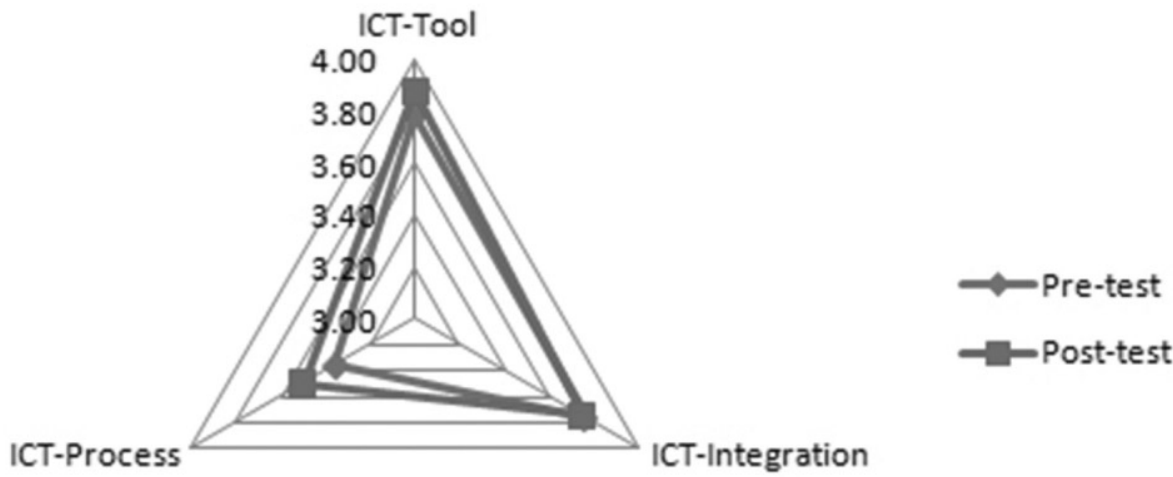

Fig. 2 Graphical representation of pre-service STEM teachers' personal belief regarding benefits of ICT in education

test is greater than the pre-test, except for the mean of ICT-Integration.

A graphical representation of the Table 3 is provided in Fig. 2, which allows us to see some belief change of the pre-service STEM teachers.

In a summary, the results provided evidence that the pre-service STEM teachers' belief about ICT in education has been changed slightly by the case-based ICT module. The results also reflect that the pre-service STEM teachers' belief change was occurred at the belief about ICT as a teaching and learning tool (ICT-Tool) and the belief about ICT in the educational process (ICTProcess) after attending the module, except for the belief about ICT integration in education (ICT-Integration). Support for the results was reported by Jimoyiannis \& Komis (2007) that teachers exhibited increased motivational and willingness to adopt ICT in education after they were exposed to ICT and case-based instruction effect change in pre-service teachers' awareness
(Lee, Summers \& Garza, 2009). On the other hand, the result on the teachers' belief about ICT integration in education is consistent with studies which have shown that the teachers' beliefs are constant and can hardly change, (Mapolelo, 2003). However, Mapolelo (2003) reported that teachers' beliefs can be changed but it comes slowly over a long period of time. In addition, the result on the teachers' belief about ICT integration in education might not be sensitive to change because the lack of real world experience in where pre-service teachers should be given the opportunities to practice teaching with technology in all teacher education courses and filed experiences (Mims et al., 2006; Richardson, 2003). Therefore, an implication of this is the possibility that case-based learning approach should be implemented into courses of teacher education program in a long time in order to effect any lasting changes in preservice teacher's belief. Moreover, the courses 
should be incorporated hands-on access to technological tools to explore their features and functions in supporting student learning effectively.

\subsection{Results for relationship between TPACK transformation and belief change}

This part of result reports an examination of the transformation of the pre-service STEM teachers' TPACK with the change of their personal belief about benefits of ICT in education. As such, the data was analyzed by bivariate relationship between the change of TPACK score and the belief using Pearson Product-Moment correlation. Table 5 shows the Pearson correlation coefficient among variables measured.
Result of correlation analysis on the relationship measured, as Table 5 shows, revealed that the correlation among the TPACK transformation and the belief change was not significant. The result indicates that there were no relationship between the transformation of their TPACK and the change of their personal belief regarding ICT in education. However, the correlation among TPACK revealed moderately strong and significant positive correlation was found between CK and PCK $(r=.806, p<.01)$, CK and TCK $(\mathrm{r}=.883, \mathrm{p}<.01), \mathrm{CK}$ and TPACK $(\mathrm{r}$ $=.744, \mathrm{p}<.01), \mathrm{PK}$ and TK $(\mathrm{r}=.763, \mathrm{p}<.01), \mathrm{PK}$ and TPK $(\mathrm{r}=.485, \mathrm{p}<.01)$, TK and TPK $(\mathrm{r}=$ $.635, p<.01)$, PCK and TCK $(r=.697, p<.01)$, PCK and TPACK $(r=.932, p<.01)$, and TCK and TPACK $(r=.697, p<.01)$. In addition, the

\section{Table 5}

Correlations among TPACK transformation and belief change regarding ICT in education

\begin{tabular}{|c|c|c|c|c|c|c|c|c|c|c|}
\hline \multirow[t]{2}{*}{ Variables } & \multicolumn{7}{|c|}{ TPACK } & \multicolumn{3}{|c|}{$\begin{array}{l}\text { Belief about } \\
\text { benefits of ICT in } \\
\text { education }\end{array}$} \\
\hline & 1 & 2 & 3 & 4 & 5 & 6 & 7 & 8 & 9 & 10 \\
\hline 1. Content Knowledge (CK) & - & & & & & & & & & \\
\hline $\begin{array}{l}\text { 2. Pedagogical Knowledge } \\
\text { (PK) }\end{array}$ & .005 & - & & & & & & & & \\
\hline $\begin{array}{l}\text { 3. Technological Knowledge } \\
\text { (TK) }\end{array}$ & .149 & $.763^{* *}$ & - & & & & & & & \\
\hline $\begin{array}{l}\text { 4. Pedagogical Content } \\
\text { Knowledge (PCK) }\end{array}$ & $.806^{* *}$ & .047 & .218 & - & & & & & & \\
\hline $\begin{array}{l}\text { 5. Technological Content } \\
\text { Knowledge (TCK) }\end{array}$ & $.883^{* *}$ & .143 & .188 & $.697^{* *}$ & - & & & & & \\
\hline $\begin{array}{l}\text { 6. Technological Pedagogical } \\
\text { Knowledge (TPK) }\end{array}$ & .084 & $.485^{* *}$ & $.635^{* *}$ & .277 & .094 & - & & & & \\
\hline $\begin{array}{l}\text { 7. Technological Pedagogical } \\
\text { and Content Knowledge } \\
\text { (TPACK) }\end{array}$ & $.744^{* *}$ & .047 & .218 & $.932^{* *}$ & $.697^{* *}$ & .277 & - & & & \\
\hline $\begin{array}{l}\text { 8. ICT as a teaching and } \\
\text { learning tool (ICT-Tool) }\end{array}$ & -.300 & .182 & .053 & -.253 & -.274 & -.055 & -.293 & - & & \\
\hline $\begin{array}{l}\text { 9. ICT integration in education } \\
\text { (ICT-Integration) }\end{array}$ & -.076 & .128 & .059 & -.024 & -.021 & .096 & -.047 & $.366^{* *}$ & - & \\
\hline $\begin{array}{l}\text { 10. ICT in the educational } \\
\text { process (ICT-Process) }\end{array}$ & -.223 & .105 & -.020 & -.107 & -.215 & .112 & -.121 & $.585^{* *}$ & $.404^{* *}$ & - \\
\hline
\end{tabular}

** denotes a correlation that significant at the .01 level 
correlation among personal belief about benefits of ICT in education revealed completely strong and significant positive correlation was found between ICT-Tool and ICT-Integration $(\mathrm{r}=.366$, $\mathrm{p}<.01)$, ICT-Tool and ICT-Process $(\mathrm{r}=.585, \mathrm{p}<$ .01), and ICT-Integration and ICT-Process $(\mathrm{r}=$ $.404, \mathrm{p}<.01)$.

In a summary, the results provided evidence that the TPACK transformation of pre-service STEM teachers is not related to their changes of belief regarding ICT in education. An implication of these findings is that development of TPACK for pre-service STEM teacher in one-year Graduate Diploma Program in Teaching Profession may not need a change of their personal belief about benefits of ICT in education.

\section{Conclusion}

This paper reported on the use of case-based learning approach to foster pre-service STEM teachers' TPACK in context of one-year Graduate Diploma Program in Teaching Profession for graduate student who finished four-year bachelor's degree in science. In a case-based ICT module, the pre-service STEM teachers have been transformed their TAPCK in STEM teaching and changed some of their belief about ICT in education. Additionally, their transformation of TPACK and belief change is not related to each other. In an effort to better serve the needs of high quality STEM teachers, the results of this study illustrated that the competency of TPACK could be particularly considered as a core attributes for future STEM teachers. By the way, case-based learning approach can play an effective part in preparing and professing the TPACK competency for STEM teachers. To foster their TPACK, the change of personal belief about benefits of ICT in education may not be required.

\section{References}

Angeli, C., \& Valanides, N. (2009).
Epistemological and methodological issues for the conceptualization, development, and assessment of ICT TPCK: Advances in technological pedagogical content knowledge (TPCK). Computers \& Education, 52, 154-168.

Baker, T. (2012). Advancing STEM Education with GIS. Retrieved October 3, 2012 from http://www.esri.com/library/ebooks/advancingstem-education-with-gis.pdf

Banks, C.M. \& Sokolowsky, J.A. (2010). Meeting the challenges of STEM education: teaching modeling and simulation with realworld applications. Paper presented at the 2010 Spring Simulation Multiconference, Orlando, Florida, USA.

Bonk, C. J., \& Zhang, K. (2008). Empowering online learning: 100+ activities for reading, reflecting, displaying, and doing. San Francisco, CA: Jossey-Bass.

Calderhead, J. (1996). Teachers: Beliefs and knowledge. In D. Berliner \& R. Calfee (Eds.), Handbook of educational psychology (pp. 709725). New York: Macmillan.

Cranston-Gingrass, A., Raines, S., Paul, J., Epanchin B., and Roselli, H. (1996). Developing and using cases in partnership environments. Teacher Education and Special Education, 19, 158-168.

Chai, C. S., Koh, J. H. L., Tsai, C.-C. \& Tan, W. L. (2011). Modeling primary school preservice teachers' Technological Pedagogical Content Knowledge (TPACK) for meaningful learning with information and communication technology (ICT). Computers \& Education, 57, 1184-1193.

Doering, A., Veletsianos, G., Scharber, C., \& Miller, C. (2009). Using the technological, pedagogical, and content knowledge framework to design online learning environments and professional development. Journal of Educational Computing Research, 41(3), 319-34

Dori, Y.J. \& Herscovitz, O. (2005). Casebased long term professional development of science teachers. International Journal of Science Education, 27(12), 1413-1446 
Edelson, D. C. (2001). Learning-for-use: A framework for the design of technologysupported inquiry activities. Journal of Research in Science Teaching, 38(3), 355-385.

Huelskamp, L.M. (2009). The impact of problem-based learning with computer simulation on middle level educators' instructional practices and understanding of the nature of middle level learners. (Doctoral dissertation). Retrieved October 3, 2012 from http://etd.ohiolink.edu/view.cgi?acc_num=osu12 42662952

Interactive Educational Systems Design. (2011). National Survey on STEM Education: Educator edition. Retrieved October 3, 2012 from http://mdcommonground. wikispaces.com/file/vie w/STEM_Report_110916.pdf

Jimoyiannis A. \& Komis V. (2007). Examining teachers' beliefs about ICT in education: implications of a teacher preparation programme, Teacher Development, 11(2), 181204

Jonassen, D., \& Hernandez-Serrano, J. (2002). Case-based reasoning and instructional design: using stories to support problem solving, Educational Technology Research \& Development, 50(2), 65-77.

Koehler, M.J., Mishra, P., \& Yahya, K. (2007). Tracing the development of teacher knowledge in a design seminar: Integrating content, pedagogy, \& technology. Computers and Education, 49(3), 740-762.

Lee, K. S., Summers, E. J., \& Garza, R. (2009). Effects of case-based learning on preservice teachers' multicultural attitudes: A mixed methods study. Academic Leadership: The Online Journal, 7(1). Retrieved May 1, 2009, from http://www.academicleadership.org/emprical_res earch/564.shtml

Lee, M.-H., Chang, C.-Y., \& Tsai, C. - C. (2009). Exploring Taiwanese high school students' perceptions of and preferences for teacher authority in the earth science classroom with relation to their attitudes and achievement. International Journal of Science Education, 31,
1811-1830.

Mapolelo, D.C. (2003). Case studies of changes of beliefs of two in-service primary school teachers. South African Journal of Education, 23(1), 71-78.

Mayo, M.J. (2009). Video Games: A Route to Large-Scale STEM Education. Science, 323, 7982.

Mishra, P., \& Koehler, M. J. (2006). Technological Pedagogical Content Knowledge: A Framework for Teacher Knowledge. Teachers College Record, 108(6), 1017-1054

Mims, C., Polly, D., Shepherd, C., \& Inan, F. (2006). Examining PT3projects designed to improve preservice education. Tech Trends, 50(3), 16-2.

Richardson, V. (2003). Preservice teachers' beliefs.In J. Raths, \& A.C. McAninch (Eds.), Teacher beliefs and classroom performance: The impact of teacher education. Advances in teacher education, Vol.6 (pp.1-22).Greenwich, CT: Information Age Publishing.

Shulman, L. S. (1986). Those Who Understand: Knowledge Growth in Teaching. Educational Researcher, 15(2), 414.

State Educational Directors Association et al. (2007). Maximizing the Impact: The pivotal role of technology in a $21^{\text {st }}$ century education system, Retrieved April 9, 2011 from http://www.p21.org /documents/ p21setdaistepaper.pdf

Sykes, G., \& Bird, T. (1992). Teacher education and the case idea. In G. Grant (Ed.), Review of research in education (Vol. 18) (pp. 457-521). Washington, DC: American Educational Research Association.

Voogt J., Tilya F. \& Van Den Akker, J. (2009) Science teacher learning for MBL-supported student-centered science education in the context of secondary education in Tanzania. Journal of Science Education and Technology 18, 429-438. 